\title{
集積可燃物密度の不確定性に着目した 津波火災ハザードマップの推定手法

\author{
A METHOD FOR ESTIMATING TSUNAMI-INDUCED FIRE HAZARD MAP \\ FOCUSING ON UNCERTAINTY OF ACCUMULATING COMBUSTIBLE DENSITY
}

\author{
西野智研*, 今津雄吾** \\ Tomoaki NISHINO and Yugo IMAZU
}

\begin{abstract}
We proposed a probabilistic method for evaluating a hazard map for tsunami-induced fire. Accumulating combustible density is visualized on the map, which represents the fire vulnerability of an arbitrary point. The density is evaluated on the basis of multiple accumulation scenarios and their occurrence probabilities using the existing model for the drift and accumulation of tsunami-driven combustible objects. The result from the application to the 2011 Tohoku Earthquake Tsunami shows that the proposed method estimates the actual fire damage zone of Yamada town plausibly.
\end{abstract}

Keymards: Tsunami-induced fire, Hazard map, Combustible density, Tsunami refuge building, Event tree, Monte Carlo simulation 津波火災, 八ザードマップ, 可然物密度, 津波避難ビル, イベントツリー, モンテカルロ・シミュレーション

\section{1. はじめに}

2011 年の東北地方太平洋沖地震の後，陸上へ汇濫を引き起こす規 模の津波に対しては，避難によって命を守る重要性が強く認識され， 各地で津波避難計画の見直しが行われている。特に, 高台への避難 に時間を要する地域では, 津波避難ビルや津波避難タワーの必要性 が指摘されており，津波避難施設の整備は，高台への避難路の整備 とあわせて，着実に進められてきた。

しかし, 東北地方太平洋沖地震では, 津波の浸水域で数多くの火 災が発生し，その一部が大規模な延焼火災に発展した結果，全域で 約 67ha が焼失した ${ }^{1)}$ 。津波の浸水域で発生する火災は「津波火災」 と呼ばれ, 家屋や自動車など, 津波に押し流された可燃物が, ガレ キとなって浸水域に集積し, そこに何らかの要因で火が着いて, 周 辺のガレキに燃え拡がることが多い 2)。特に, 津波からの一時避難 場所となった建物が, 津波火災によって類焼し, 避難者が火災の危 険に曝された事例 344) や, 津波火災が林野に延焼し, 自然地形の高 台が被害を受けた事例 ${ }^{5}$ が報告されている。こうした事態は, 津波 避難施設や高台において考慮すべき新たな危険要因の存在を浮き彫 りにしたが, 現在の津波避難計画では, 津波火災から避難者を保護 するための対策は，ほとんど検討されていない。

津波火災によって被害を受けやすい場所とそうでない場所を，地 図上に可視化した八ザードマップがあれば，津波避難施設の配置や 火災安全対策を合理的に検討できる可能性がある。筆者ら ${ }^{6}$ は, 津 波によって建物から流出する可燃物が, 浸水域のどこにどの程度集 積するのかを，物理的に予測するモデルの開発を行ってきた。この
モデルでは，津波氾濫流の流況を既知とし，流出可燃物に作用する 力の釣り合いを時系列に解くことで，可燃物の位置を個別に追跡し， 浸水域全体での可燃物の空間分布の評価につなげる。津波火災の被 害範囲が可燃物の集積範囲と密接な関係にある点に着目すると, 評 価される集積可燃物量の空間分布は，津波火災ハザードマップの危 険度指標として，簡単で要点をつかんでいる。しかし，集積可燃物 量の空間分布は，津波や建物の被害といった複数の不確定条件に左 右される。このため, 予想される様々な集積シナリオとその生起確 率を基に, 集積可燃物量を確率論的に評価する手法が必要である。 そこで本研究では, 既往のモデル6) を用いて, 津波火災危険度の 空間的ばらつきを，集積可燃物量に着目して確率論的に評価する手 法の提案を目的とする。この手法による評価結果を，津波火災八ザ ードマップとして展開することで, 津波避難施設の配置や指定要件 の見直し，火災安全対策の検討に活用されることを目指す。

\section{2. 本研究で活用する計算モデルの概要}

\section{1 可燃物の漂流・集積モデル $\left.{ }^{6}\right)$}

本研究で活用寸る可燃物の漂流・集積モデルは，近年の地震被害 想定において，活用の実績のある津波数值解析 注 1 ) と連携し，津波 氾濫流の流況を既知とした物理的な定式化がなされている。このモ デルでは，津波火災の燃え拡がりに寄与する主要な可燃物として， 建物から流出する可燃物に着目し，津波に流される個々の可然物に 作用する力の釣り合いを時系列に解くことで，可然物の位置を個別 に追跡する。力の釣り合いを記述する運動方程式については，回転
$*$ 国立研究開発法人建築研究所 主任研究員 $\cdot$ 博士 (工学 $)$

** 清水建設侏技術研究所 主任研究員 $\cdot$ 修士 (工学)
Senior Research Engineer, Building Research Institute, Dr. Eng.

Senior Research Engineer, Institute of Technology, Shimizu Corp., M. Eng. 
運動を無視し, 水平方向の重心の並進運動のみを扱って, 慣性, 抗 力, 水流の圧力勾配, 付加質量, 残存建物との衝突力の 5 種類の作 用を考慮した次の式で表す。

$$
\begin{aligned}
\underbrace{m_{d, i} \frac{\partial \mathbf{u}_{d, i}}{\partial t}}_{\text {慣性 }} & =\underbrace{\frac{1}{2} C_{d} \rho_{w} A_{d, i}\left(\mathbf{u}_{w, i}-\mathbf{u}_{d, i}\right)\left|\mathbf{u}_{w, i}-\mathbf{u}_{d, i}\right|}_{\text {抗力 }}+\underbrace{\rho_{w} V_{d, i} \frac{\partial \mathbf{u}_{w, i}}{\partial t}}_{\text {水流の圧力勾配 }} \\
& +\underbrace{\rho_{w} C_{m} V_{d, i}\left(\frac{\partial \mathbf{u}_{w, i}}{\partial t}-\frac{\partial \mathbf{u}_{d, i}}{\partial t}\right)}_{\text {付加質量 }}-\underbrace{\phi_{1} \phi_{2} w_{d, i} m_{d, i} \mathbf{u}_{d, i}\left|\mathbf{u}_{d, i}\right|}_{\text {残存建物との衝突力 }}
\end{aligned}
$$

ここに, $i$ は可燃物の識別記号, $m_{d, i}$ は可燃物の質量, $\mathbf{u}_{d, i}$ は可燃 物の速度, $\mathbf{u}_{w, i}$ は水の速度, $\rho_{w}$ は水の密度, $A_{d, i}$ は可燃物の水面 下部分を流れ方向に投影した面積, $V_{d, i}$ は可燃物の水面下部分の体 積, $w_{d, i}$ は可燃物の幅, $C_{d}$ は抗力係数, $C_{m}$ は付加質量係数, $\phi_{1}$ は 定数, $\phi_{2}$ は残存建物の面積占有率, $t$ は時間である。

また，可燃物の位置 $\mathbf{X}_{d, i}$ は，力の釣り合いから定まる決定論的な 位置と, 水流の乱れに起因寸るそこからの不確定なずれ（拡散）の 和であるとみなし，

$$
\mathbf{X}_{d, i}^{(n+1)}=\underbrace{\mathbf{X}_{d, i}^{(n)}+\mathbf{u}_{d, i}^{(n)} \Delta t+\frac{1}{\partial t} \frac{\partial \mathbf{u}_{d, i}^{(n)}}{y^{2}} \Delta t^{2}}_{\text {決定論的な位置 }}+\underbrace{\sqrt{24 \boldsymbol{\kappa}_{d, i} \Delta t}\left(\xi_{i}^{(n)}-\frac{1}{2}\right)}_{\text {不確定なすれ (拡散) }}
$$

ここに, $n$ は現在の時間ステップ, $n+1$ は次の時間ステップ, $\boldsymbol{\kappa}_{d, i}$ は拡散係数, $\Delta t$ は時間刻み, $\xi_{i}$ は $0 \sim 1$ の一様乱数である。

集積可燃物量の評価にあたっては, 津波に流される可燃物が移動 を停止し, 地面に漂着寸る条件が必要になる。ここでは, 可然物の 底面が地面に接触した時点で, 移動を停止するとみなし, 周囲の水 深が可燃物の浮遊に必要なそれ $h_{c r}$ を下回った時点とする。

$h_{c r}=\left(\rho_{d, i} / \rho_{w}\right) h_{d, i}$

ここに, $\rho_{d, i}$ は可燃物の密度, $h_{d, i}$ は可燃物の厚さである。なお, 可燃物が一度漂着しても, 周囲の水深が浮遊に必要なそれを上回れ ば，移動が再開される。
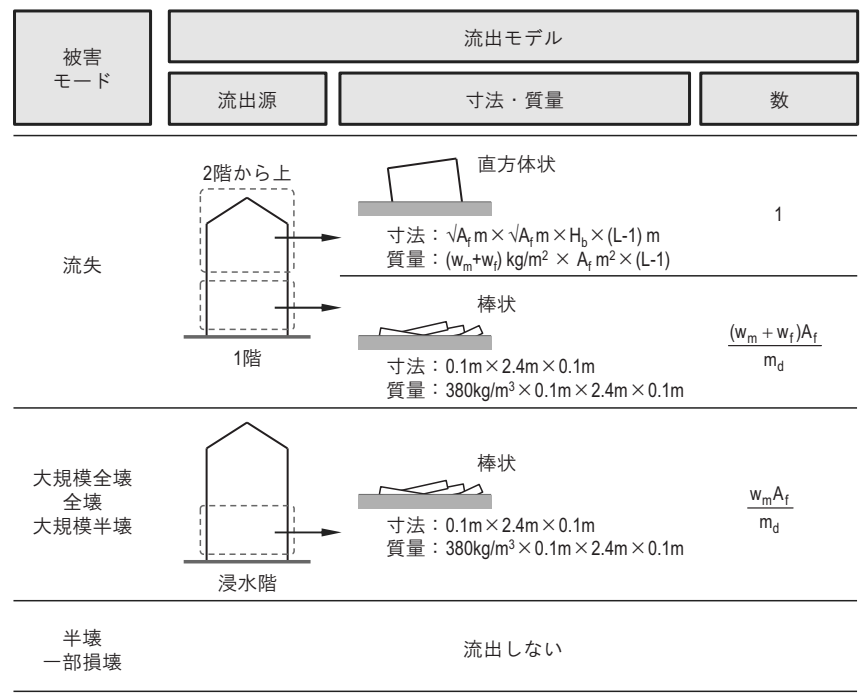

$A_{f}$ : 建築面積 $\left(m^{2}\right) \quad w_{m}$ : 収納可燃物密度 $\left(\mathrm{kg} / \mathrm{m}^{2}\right) \quad \mathrm{w}_{\mathrm{f}}$ : 固定可燃物密度 $\left(\mathrm{kg} / \mathrm{m}^{2}\right)$

$H_{b}$ : 階高 $(\mathrm{m}) \quad \mathrm{L}$ : 階数 $(-) \mathrm{m}_{\mathrm{d}}$ : 流出する可燃物の質量 $(\mathrm{kg})$

図 1 可燃物の流出モデルと建物の被害モードの関係

\section{2 可燃物の流出モデル}

可燃物の漂流・集積モデル 6)を活用した評価では，建物から流出 する可燃物の数や初期位置, 寸法や質量を, 入力条件として与える 必要がある。本研究では, 津波による建物の被害を, 流失や全壊と いった状態（被害モード）で定義し，可燃物の流出条件（流出モデ ル）と対応させることで, 流出する可燃物の数や初期位置, 寸法や 質量を決定する。

図 1 に, 被害モードと流出モデルの関係を示す。本研究では, 国 土交通省の建物被害区分 ${ }^{7)}$ に倣い，被害モードを，流失・大規模全 壊・全壊・大規模半壞・半壊・一部損壊の 6 区分に分類する注2)。こ こでは, 各被害モードに対応する流出モデルを，次のように仮定す る。

\section{(1) 流失}

建物の 1 階については，津波によって構造が完全に破壊されると 考え, 形状・質量が一様な棒状の可燃物となって流出する。この棒 状の可燃物については, 柱や梁といった構造材の代表的な寸法とし て, 幅 $0.1 \mathrm{~m}$ ・奥行き $2.4 \mathrm{~m} ・$ 高さ $0.1 \mathrm{~m}$ を仮定し，代表的な樹種であ る杉の密度 $380 \mathrm{~kg} / \mathrm{m}^{3}$ を用いて, 質量を与える。

建物の 2 階から上については，構造を保持したまま流出すると考 え, 直方体状の単独の可燃物（一つの固まり）となって流出する。 この直方体状の可燃物については，幅と奥行きに当該建物の建築面 積の平方根 $\sqrt{A_{f}}$ を, 高さに 2 階床面から屋根までの高さを仮定し, 質量は，2 階から上に収納・固定される可燃物の重量を与える。

\section{（2）大規模全壊・全壊・大規模半壊}

柱や梁，外壁といった建物の主要構造は，津波に流されず，浸水 階に収納される家具のみが流出すると考え，形状・質量が一様な棒 状の可燃物となって流出する。この棒状の可燃物の寸法と質量は, 流失の場合と同様に与える。

\section{(3) 半壊・ 一部損壊}

可燃物の流出は生じない。

このとき, 流出する可燃物の数は，基本的に，流出源となる階に収 納・固定される可燃物の重量を, 流出する可燃物の質量で割ること によって，算出される。

$n_{L}=\frac{\left(w_{m}+w_{f}\right) A_{f}}{m_{d, i}}$

ここに, $n_{L}$ は階から流出する可燃物の数， $w_{m}$ は収納可燃物密度， $w_{f}$ は固定可燃物密度, $A_{f}$ は建築面積である。なお, 大規模全壊・ 全壊・大規模半壊の建物については, 固定可燃物密度 $w_{f}$ を無視す る。また, 流出する可燃物の初期位置は, 当該建物の重心から, 建 築面積の平方根 $\sqrt{A_{f}}$ の圈内で, ランダムに与える。

\section{3. 津波火災危険度の確率論的評価手法}

図 2 に, 津波火災危険度の確率論的評価手法の概念を示す。ここ では，ある地点の津波火災による被害の受けや寸さを表す危険度指 標として，その地点に最終的に漂着する可燃物の単位面積あたりの 総重量（以降では，集積可燃物密度と呼ぶ）に着目する注3）。集積可 燃物密度を評価する可燃物には，地域によらず普遍的に存在し，初 期位置の特定が容易な，建物に収納・固定される可然物を扱う。な お，津波火災の燃え拡がりには，自動車や LP ガスボンベといった 
可燃物も関与寸ることが考えられるが，初期位置の特定が容易でな いことや，後者については，地域によらず普遍的に存在する訳では ないことを踏まえ, 本研究では, 扱わない。

本研究では, 集積可燃物密度を左右する不確定要因として, 次の 4 種類の要因を考慮する。

(1) 津波来襲時の潮位

(2) 防潮堤といった海岸構造物の被害

(3) 津波による建物の被害

(4) 建物に収納・固定される可燃物の密度

(1) と (2) は，津波汇濫流の流況に影響を及ぼす不確定要因であり，(3) と (4)は, 流出する可燃物の数や初期位置に影響を及ぼす不確定要因 である。ただし, 津波汇濫流の流況は, 津波の発生する領域や断層 のすべり量といった津波断層モデルの不確定性にも, 大きく影響を 受ける。わが国の近海での発生が想定される津波については, 津波

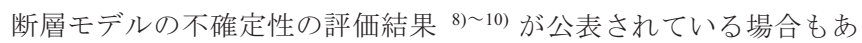
り, 津波火災の危険度評価に, こうした成果を活用することは可能 である。しかし，こうした成果は，被災後の影響が特に大きい重要 施設を対象として, 設計外力の決定に利用されることを想定したも のであり, 本研究での津波火災八ザードマップの利用目的に, 必ず しも馴染むとは限らない。そこで, 津波断層モデルの不確定性を含 めた危険度評価は, 今後の検討課題とし, 本研究では, 津波断層モ デルを与条件とすることで，津波の発生を決定論的に扱う。

\section{1 ネットの集積可燃物密度の定義}

火災安全工学では, 可燃物の種類や大きさによって, 完全燃焼し た際の発熱量が異なることを考慮し, 可燃物の重量は, 発熱量が等 価な木材の重量に換算されることが多い 11)12)。本研究でも, 発熱量 の違いが重量に反映される木材換算重量を用いて, 集積可燃物密度 を評価し, 密度の評価単位には, メッシュを用いる。このとき, あ る津波汇濫流 $j$ によって, 最終的にメッシュ $k$ に漂着する可燃物の 集積可燃物密度 $w_{j k}$ は, 次のように表される。

$w_{j k}=\frac{\sum_{i=1}^{n_{j}}\left(\delta_{i j k} \Delta H_{i} M_{i}\right) / \Delta H_{w}}{d^{2}}=\frac{\sum_{i=1}^{n_{j}}\left(\delta_{i j k} m_{d, i}\right)}{d^{2}}$

ここに, $n_{j}$ は津波氾濫流 $j$ によって流出する可燃物 $i$ の数, $\Delta H_{i}$ は 可燃物 $i$ の単位重量あたりの発熱量, $\Delta H_{w}$ は木材の単位重量あたり の発熱量, $M_{i}$ は可燃物 $i$ の重量, $m_{d, i}$ は可燃物 $i$ の木材換算重量, $\delta_{i j k}$ は津波汇濫流 $j$ によって可燃物 $i$ がメッシュ $k$ に漂着する場合 を 1 , そうでない場合を 0 とするダミー変数, $d$ はメッシュの幅で ある。

津波氾濫流 $j$ が与えられた時, 流出寸る可燃物の数や初期位置の 組み合わせは，事実上，無限に存在することから，最終的にメッシ ュ $k$ に漂着する可然物の集積可燃物密度 $w_{j k}$ は, 確率変数である。 また, 津波氾濫流 $j$ も, 潮位や海岸構造物の被害によって, 流況は 無限に存在する。本研究では, 津波氾濫流 $j$ が与えられた時の集積 可燃物密度 $w_{j k}$ が, 平均 $\mu_{j k}$, 標準偏差 $\sigma_{j k}$ の正規分布,

$$
f\left(w_{j k}\right)=\frac{1}{\sqrt{2 \pi \sigma_{j k}^{2}}} \exp \left\{-\frac{\left(w_{j k}-\mu_{j k}\right)^{2}}{2 \sigma_{j k}^{2}}\right\}
$$

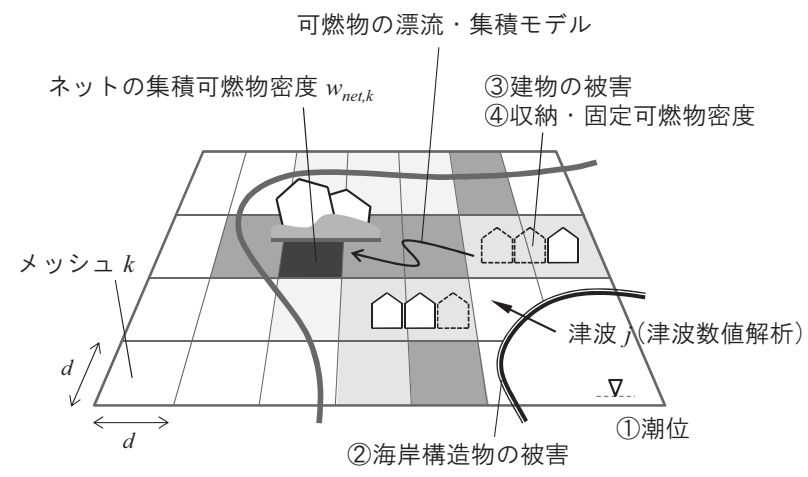

図 2 津波火災危険度の確率論的評価手法の概念

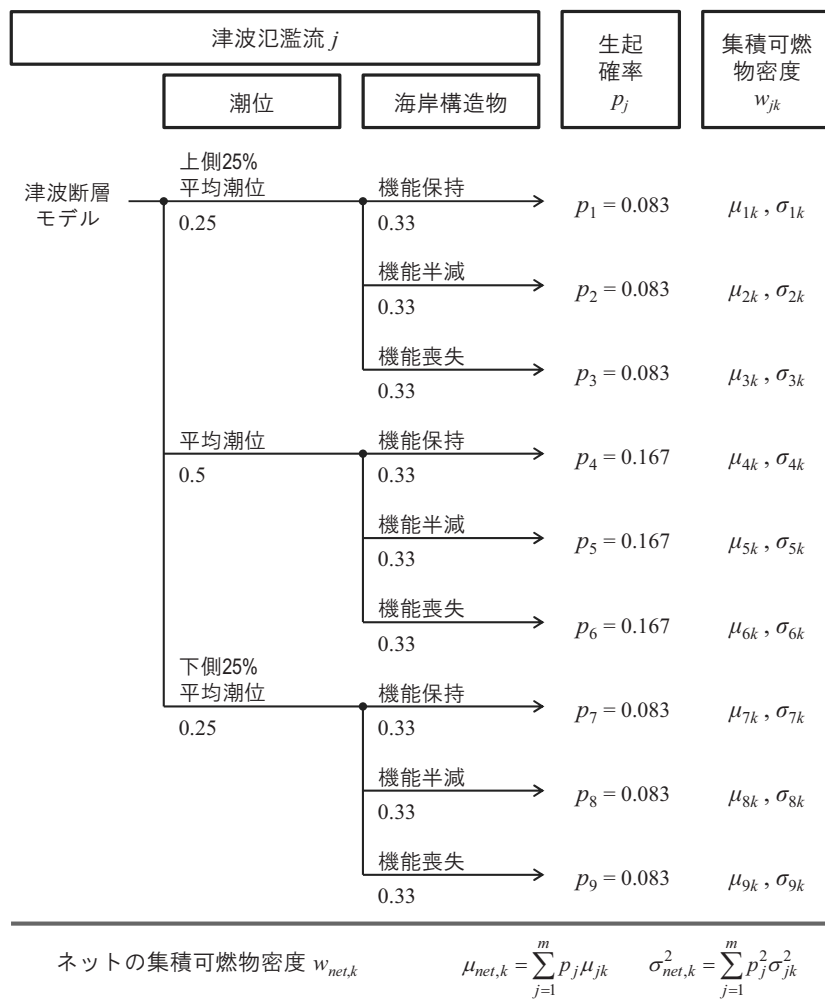

図 3 ネットの集積可燃物密度の評価の考え方

に従うと仮定し, あらゆる津波汇濫流の生起確率が反映されたネッ トの集積可燃物密度 $w_{n e t, k}$ を, 次のように定義する。

$w_{n e t, k}=\sum_{j=1}^{\infty} p_{j} w_{j k} \quad\left(\right.$ ただし,$\left.\sum_{j=1}^{\infty} p_{j}=1\right)$

ここに, $p_{j}$ は津波の発生を決定論的に扱った場合の津波汇濫流 $j$ の 生起確率である。ここで, 正規分布に従う独立な確率変数の和が正 規分布に従うことに注意すると, ネットの集積可燃物密度 $w_{n e t, k}$ も また, 正規分布に従い, その平均 $\mu_{n e t, k}$ と標準偏差 $\sigma_{n e t, k}$ は, 次のよ うに表される。

$\mu_{n e t, k}=\sum_{j=1}^{\infty} p_{j} \mu_{j k}, \quad \sigma_{n e t, k}^{2}=\sum_{j=1}^{\infty} p_{j}^{2} \sigma_{j k}^{2}$

そこで本研究では, ネットの集積可燃物密度の平均 $\mu_{n e t, k}$ と標準偏 差 $\sigma_{n e t, k}$ を，工学的に評価することを検討する。 


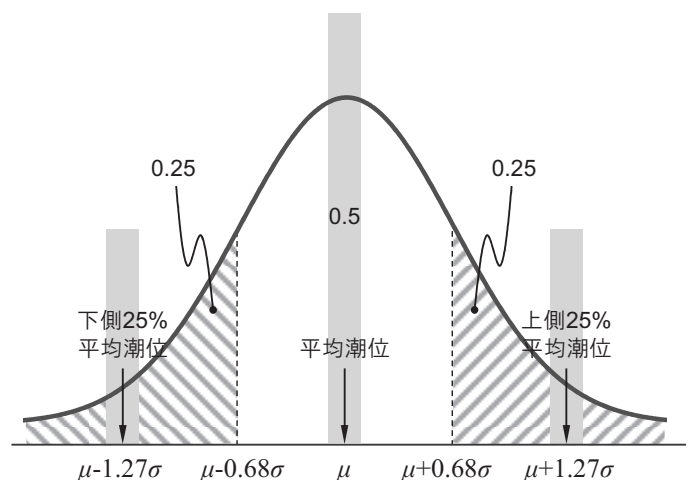

図4 正規分布を仮定した潮位の離散確率分布への変換

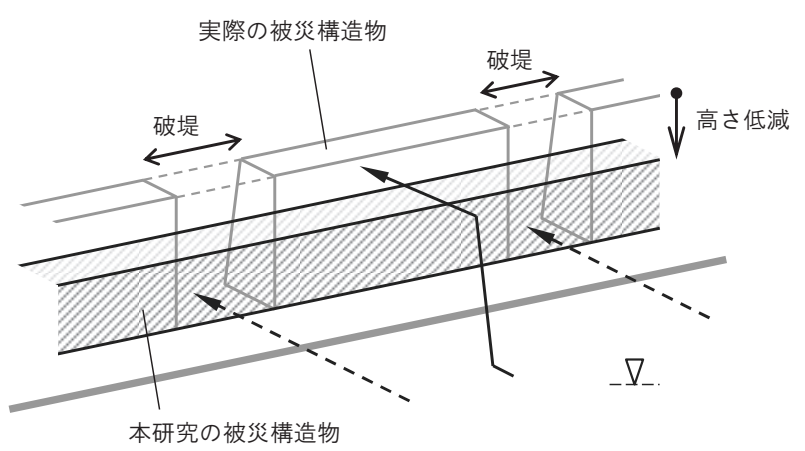

図 5 高さ低減による海岸構造物の被害の簡略化

\section{2 不確定要因の扱い方}

図 3 に, ネットの集積可燃物密度の評価の考え方を示す。本研究 では，イベントツリーとモンテカルロ・シミュレーションを併用す ることで, 有限個のシナリオを抽出し, それらを基に, ネットの集 積可燃物密度を評価する。ここでは，

・津波汇濫流の流況に影響を与える不確定要因(1)と(2) (離散確 率分布として扱い, イベントッリーを作成することで, 評価に 用いる津波氾濫流のシナリオとその生起確率を決定する。

- 流出する可燃物の数や初期位置に影響を与える不確定要因(3) と (4)は，連続確率分布として扱い，乱数を用いて，可燃物の数や 初期位置を決定する。この手続きを十分な回数試行し, 可燃物 の漂流・集積モデルの入力条件とすることで, 津波氾濫流 $j$ が 与えられた時の集積可燃物密度の平均 $\mu_{j k}$ と標準偏差 $\sigma_{j k}$ を評 価する。

なお, 津波汇濫流の流況に影響を与える不確定要因(1)と (2)を, 離散 確率分布として扱うのは, 一回の津波数值解析に要する時間が長い ことから, シナリオ数を削減することで, 手法の簡便性を確保する ことを考えた。

ネットの集積可燃物密度の平均 $\mu_{n e t, k}$ と標準偏差 $\sigma_{n e t, k}$ は, 評価に 用いる津波汇濫流のシナリオ数を $m$ として, 次のように書き直され る。

$\mu_{n e t, k}=\sum_{j=1}^{m} p_{j} \mu_{j k}, \quad \sigma_{n e t, k}^{2}=\sum_{j=1}^{m} p_{j}^{2} \sigma_{j k}^{2}$

したがって, 本研究での津波火災危険度の評価は, 津波氾濫流 $j$ の
生起確率 $p_{j}$ を求め, その下での集積可燃物密度の平均 $\mu_{j k}$ と標準偏 差 $\sigma_{j k}$ を評価し, ネットの集積可燃物密度の平均 $\mu_{n e t, k}$ と標準偏差 $\sigma_{n e t, k}$ を算出することに帰着する。

\section{(1) 津波来襲時の潮位}

海面は，天体間で働く潮汐力によって，周期的に上下寸ることが 知られており，台風といった異常気象時に生じる高潮を除けば，潮 位を確率変数と考えることはできない。しかし，地域ごとに公開さ れている潮汐表から，1 時間ごとの潮位を積み上げ，度数分布とし て表現すれば，左右対称の釣り鐘型分布に近い形が得られ，統計的 な変数として扱うことが可能になる ${ }^{13)}$ 。

そこで本研究では, 潮位の周期的な変動を正規分布で近似した上 で，離散確率分布に変換する。ここでは，図 4 に示すように，正規 分布の面積を, 下側 $25 \%$, 中央值周辺 $50 \%$, 上側 $25 \%$ の 3 つの領域 に分割し，それぞれの領域の重み付き平均を，離散確率分布の確率 変数に設定する。正規分布表によれば，各領域の境界点は，平均士 $0.68 \sigma$ の位置に対応寸ることから, 各領域の重み付き平均は, 下側 から順に, 平均 $-1.27 \sigma$, 平均, 平均 $+1.27 \sigma$ と計算される。本研 究では, 平均と標準偏差 $\sigma$ を, 地域ごとに公開されている潮汐表か ら算出し, 離散確率分布に従う 3 つの潮位の值を決定する。

\section{(2) 防潮堤といった海岸構造物の被害}

兵庫県南部地震（1995）や東北地方太平洋沖地震（2011）による 海岸構造物の被害調查結果 ${ }^{14)}$ 17) から, 海岸構造物の被害には, 地 震による堤体の損傷・倒壊や地盤の沈下，津波による堤体の滑動・ 転倒や地盤の洗掘, クラックの発生など, 複数の形態が存在するこ とが知られている。海岸構造物のどこが，どの破壊形態によって， どの程度機能を失うかは, 海岸構造物の構造や整備年代, 津波の強 さといった様々な要因に左右されると予想される。しかし，現状で は，関連する知見が不足しており，こうした複雑な要因の影響を合 理的に考慮して, 被害の評価を行うことは難しい。また，被害の位 置の不確定性を考慮すれば, 津波氾濫流のシナリオ数が莫大になる が，津波数值解析の負荷を考えると，簡便性を欠き過ぎる。

そこで本研究では, 海岸構造物の全ての位置で, 同時に平均的な 被害が生じると仮定し，被害の位置の不確定性を無視する。ここで は，図 5 のように，海岸構造物の高さを，場所によらず一定の割合 で低減させることとし, 機能保持 (低減率 $0 \%$ ), 機能半減（低減率 $50 \%$ ），機能喪失（低減率 $100 \%$ ）の 3 つのイベントに離散化する。 ただし，各イベントの生起確率については，合理的な設定が困難な ことから, 現状では, 一律に $1 / 3$ として, 各イベントの影響を均等 に扱うこととする。

\section{(3) 津波による建物の被害}

津波による建物の被害を確率論的に予測する手法として，既往の 津波による建物の被害と，津波氾濫流の流体力学的な諸量との関連 を統計的に推定した津波被害関数 ${ }^{18)}$ 20) が提案されている。この津 波被害関数は，流失といった被害モードの生起確率と，浸水深とい った津波外力指標との関連に，正規分布や対数正規分布を仮定した 次の式で表されることが多い。

$P_{D}=\Phi\left[\frac{X-\mu}{\sigma}\right] \quad, \quad P_{D}=\Phi\left[\frac{\ln X-\lambda}{\xi}\right]$

ここに, $P_{D}$ は被害モードの生起確率， $\Phi$ は標準正規分布の累積分 


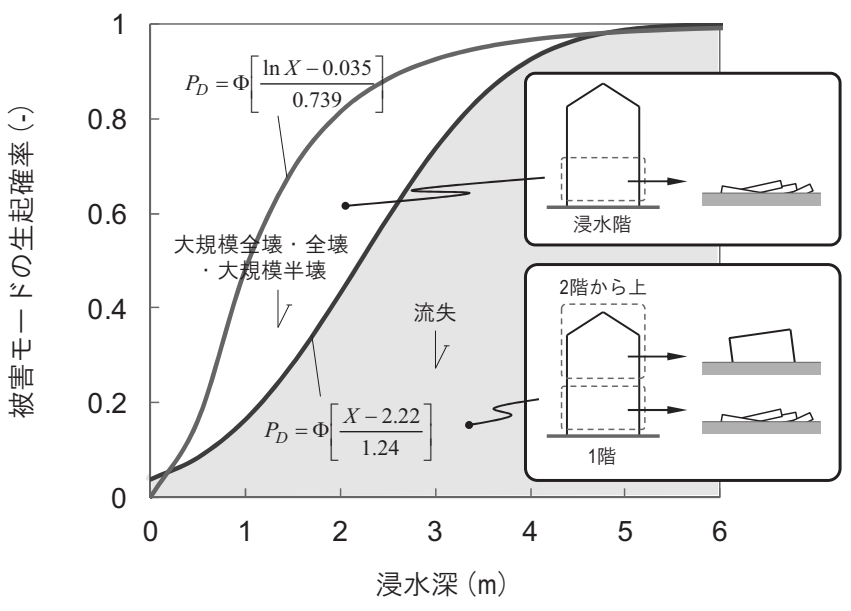

図 6 本研究で用いる津波被害関数 ${ }^{20)}$

布関数, $X$ は浸水深, 最大流速, 最大抗力といった津波外力指標, $\mu$ (または $\lambda), \sigma($ または $\xi$ ) はそれぞれ $X$ または $\ln X$ の平均と標 準偏差である。特に, Suppasri ら ${ }^{20)}$ は, 東北地方太平洋沖地震津波 の建物被害データ7) を用いて, 浸水深を説明変数にとった津波被害 関数を, 建物の構造別に推定している。

そこで本研究では, 東北地方太平洋沖地震津波の津波被害関数 ${ }^{20)}$ を用いて, 浸水深から建物の被害モードを確率論的に決定する。こ の津波被害関数では, ある規模以上の被害が生じる確率が予測され る。ここでは, 簡単のため, 被害モードの予測は, 木造の建物のみ を対象とし, 可燃物の流出モデルとの対応から, 流失被害が生じる 確率と, 大規模半壊以上の被害が生じる確率を予測する津波被害関 数を用いる。前者は, $\mu=2.22, \sigma=1.24$ の正規分布で, 後者は, $\lambda=0.035, \xi=0.739$ の対数正規分布でモデル化される（図 6)。

\section{(4) 建物に収納・固定される可燃物の密度}

既往の可燃物調查の結果 $\left.{ }^{21} 22\right)$ から, 収納可燃物の密度は, 建物や 室の用途によって, 大きくばらつくことが知られている。本研究で は, 収納可燃物密度 $w_{m}$ が正規分布に従うと仮定し, 代表的な建物 用途における平均と標準偏差を，表１のように設定することで，確 率論的に決定する。一方, 固定可燃物の密度は, 用途によるばらつ きは大きくなく, 建物の構造によって決まると考えられる。本研究 では, 固定可燃物密度 $w_{f}$ の設定は, 木造の建物のみを対象とし, 既往の実大火災実験に使用された木造家屋の固定可燃物密度の算定 結果 ${ }^{23)}$ を基に, 平均的な值を決定論的に与える。ここでは, 屋根の 重量が含まれる最上階の固定可燃物密度に $150 \mathrm{~kg} / \mathrm{m}^{2}$ を, 途中階のそ れに $60 \mathrm{~kg} / \mathrm{m}^{2}$ を採用する。

\section{4. 東北地方太平洋沖地震への適用による評価特性の確認}

本研究で提案する手法の評価特性を確認するため, 東北地方太平 洋沖地震津波を対象とした津波火災危険度の評価を行った。ここで は, 津波の浸水域で 2 件の火災が発生し, 約 16ha を焼失する大規模 火災に発展した岩手県山田町中心部 ${ }^{1)}$ に着目する。

\section{1 計算条件}

表 2 に, 計算条件を示す。本研究では, モンテカルロ・シミュレ ーションは, 100 回の試行とし, 各試行につき, 地震から 6 時間分 のシミュレーションを行って, 津波氾濫流 $j$ が与えられた時の集積
表 1 建物用途別の収納可燃物密度の平均と標準偏差の設定 ${ }^{2122)}$

\begin{tabular}{|c|c|c|c|c|}
\hline \multirow{2}{*}{\multicolumn{2}{|c|}{ 建物用途 }} & \multirow{3}{*}{$\begin{array}{l}\text { 対象施設の例 } \\
\text { 専用住宅 }\end{array}$} & \multicolumn{2}{|c|}{$\begin{array}{c}\text { 収納可燃物密度 } \\
\left(\mathrm{kg} / \mathrm{m}^{2}\right)\end{array}$} \\
\hline & & & 平均 & S.D. \\
\hline \multirow{5}{*}{ 住宅系 } & 住宅 & & 20.0 & 6.5 \\
\hline & 共同住宅 & アパート, マンション, 寮 & 36.4 & 11.7 \\
\hline & 店舗併用住宅 & 事務所や店舗が併設 & 36.4 & 11.7 \\
\hline & 作業所併用住宅 & 工業系の施設が併設 & 36.4 & 11.7 \\
\hline & その他 & & 20.0 & 6.5 \\
\hline \multirow{3}{*}{ 商業系 } & 商業施設 & 物販系の施設 & 19.2 & 8.6 \\
\hline & 業務施設 & 事務所系の施設 & 30.1 & 11.3 \\
\hline & その他 & & 30.1 & 11.3 \\
\hline \multirow{3}{*}{ 工業系 } & 運輸倉庫施設 & 駅舎系の施設 & 1.1 & 0.6 \\
\hline & 工業施設 & 工場 & 85.8 & 70.1 \\
\hline & その他 & & 85.8 & 70.1 \\
\hline 公共系 & 公共公益施設 & 庁舎·学校·公民館 & 30.1 & 11.3 \\
\hline \multirow{2}{*}{ その他 } & 農林漁業用施設 & 納屋·温室·船小屋 & 0.0 & 0.0 \\
\hline & その他 & 処理場·浄水場 & 30.1 & 11.3 \\
\hline
\end{tabular}

表 2 計算条件（東北地方太平洋沖地震 $\cdot 山$ 田町）

\begin{tabular}{|c|c|c|}
\hline \multicolumn{2}{|c|}{ 項目 } & 設定 \\
\hline \multicolumn{2}{|c|}{ 津波氾濫流のシナリオ数 } & 9 \\
\hline \multicolumn{2}{|c|}{ 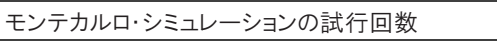 } & 100 \\
\hline \multicolumn{2}{|c|}{ 計算時間 } & $6 \mathrm{hrs}$ \\
\hline \multirow{2}{*}{ 時間刻み } & 津波氾濫流の流況 & $0.1 \mathrm{~s}$ \\
\hline & 可燃物の位置変化 & $0.6 \mathrm{~s}$ \\
\hline \multirow{2}{*}{ メッシュの幅 } & 津波氾濫流の流況 & $10 \mathrm{~m}$ \\
\hline & 集積可燃物密度 & $50 \mathrm{~m}$ \\
\hline \multicolumn{2}{|l|}{ 津波断層モデル } & 東北大学モデル \\
\hline \multirow{3}{*}{ 潮位 } & 上側 $25 \%$ 平均潮位 & $0.412 \mathrm{~m}$ \\
\hline & 平均潮位 & $0.000 \mathrm{~m}$ \\
\hline & 下側 $25 \%$ 平均潮位 & $-0.412 m$ \\
\hline \multirow{3}{*}{$\begin{array}{l}\text { 海岸構造物の高さ } \\
\text { (防潮堤) }\end{array}$} & 機能保持 & $4 \mathrm{~m}$ \\
\hline & 機能半減 & $2 \mathrm{~m}$ \\
\hline & 機能喪失 & $0 \mathrm{~m}$ \\
\hline \multirow{2}{*}{ 建物 } & 位置·形状·階数 & 住宅地図 \\
\hline & 構造·用途 & 復興支援調査アーカイブ \\
\hline
\end{tabular}

可燃物密度の平均 $\mu_{j k}$ と標準偏差 $\sigma_{j k}$ を評価する。津波氾濫流のシ ナリオ数は, 9 通りであるため, 合計で 900 通りの集積シナリオと その生起確率を基に, ネットの集積可燃物密度の平均 $\mu_{n e t, k}$ と標準 偏差 $\sigma_{n e t, k}$ を評価することになる。この集積可燃物密度の評価単位 であるメッシュの幅は，50m と設定した。

津波の発生領域や断層のすべり量を与える津波断層モデルには, 東北地方太平洋沖地震津波の浸水範囲を良好に再現できるように調 整された東北大学モデル ${ }^{24)}$ を用いた。潮位については, 山田町に近 い宮古市の 1 年分の潮汐表から, 平均と標準偏差を求め, 3 種類の 潮位を算出した。その結果，上側 $25 \%$ 平均潮位は， $0.412 \mathrm{~m}$, 平均潮 位は， $0.000 \mathrm{~m}$ ，下側 $25 \%$ 平均潮位は， $-0.412 \mathrm{~m}$ となった。海岸構造 物については，当時設置されていた高さ $4 \mathrm{~m}$ の防潮堤を基準（機能 保持の条件）とし，機能半減の条件では，高さを $2 \mathrm{~m}$ に，機能喪失 の条件では, 高さを $0 \mathrm{~m}$ にすることで, 海岸構造物の被害の影響を 考慮した。

建物の位置・形状・階数は, 地震前の市街地状況が分かる住宅地 図から把握し，3,252 棟の建物をデータ化した。また, 建物の構造 
と用途は, 復興支援調査アーカイブ 25) の建物被災状況データから, 特定した。

建物の被害モードの決定に必要な浸水深は, 建物の重心位置にお ける水深の最大值を, 津波数值解析から事前に求めておくことで与 える。また, 建物から可燃物が流出する時間は, 早くても, 床上以 上の浸水が生じた時点と考え, 水深が $0.3 \mathrm{~m}$ を超えた時点と仮定し た。

抗力係数 $C_{d}$ は, 物体の形状や流れの方向に依存することが知ら れている。棒状の可燃物については, 流れの方向と可燃物の中心軸 が常に一致すると仮定し, 水面に浮遊させた円柱棒に作用寸る流体 力を調べた既往の水理実験の結果 ${ }^{26)}$ を用いる。また, 直方体状の可 燃物については, 流孔の方向と可燃物の水平断面の間に, 仰角が生 じないと仮定し, 水路に置かれた正角柱に作用する流体力を調べた 既往の水理実験の結果 ${ }^{27)}$ を用いる。ここでは, 抗力係数 $C_{d}$ を, 次 のように与える。

棒状 : $\quad C_{d}=\left(0.89(l / w)^{0.01}+32.5 R e^{-1 / 2}\right)^{2}+0.01(l / w) F r^{0.25}$

直方体状 : $C_{d}=2.12$

ここに, l は可燃物の長さ, $w$ は可燃物の幅, Re はレイノルズ数, Fr はフルード数である。なお, 直方体状の可然物については, レ イノルズ数が大きく, 水路の幅が正角柱の幅に対して, 十分に大き い場合の值を用いた。

付加質量係数 $C_{m}$ については, 既往の水理実験の結果 ${ }^{26)}$ から, 長 細比 $l / w$ によらず, 概ね一定の值をとることが示されている。そこ で, 付加質量係数 $C_{m}$ は, 可燃物の形状によらず, 0.78 を与えた。

拡散係数 $\kappa$ にいては, いくつかの水理実験の結果 ${ }^{26) 2829)}$ から, 摩擦速度 $u_{*}$ と水深 $h$ で無次元化した拡散係数 $\kappa / u_{*} h$ は, $0.032 \sim 0.23$ の值をとることが示されている。ここでは, この結果を参考に, 無 次元拡散係数 $\kappa / u_{*} h$ を 0.2 と設定した。

残存建物との衝突力を左右する定数 $\phi_{1}$ については, 当該地域を対 象に実施した既往のケーススタディ ${ }^{6)}$ の結果から, 津波火災の焼失 範囲に集積する可燃物の総重量を, 最大化するように調整された值 として, 0.1 を用いる。

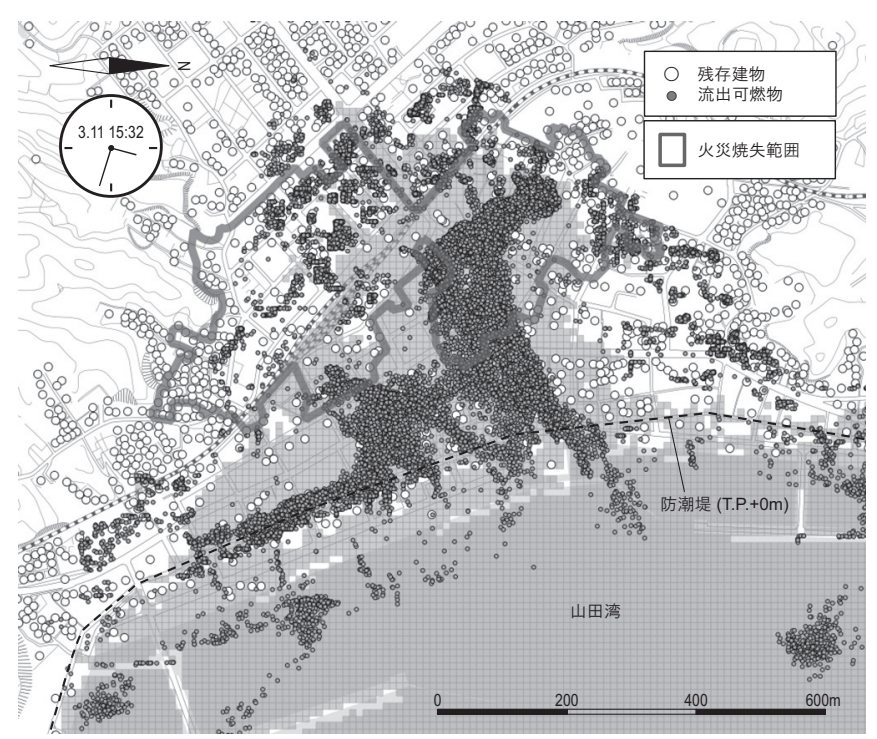

図 7 可燃物の漂流・集積シミュレーション結果の一例

\section{2 計算結果と考察}

図 7 に, シミュレーション結果の一例を示す。本研究では, 津波 に流される可燃物の位置を個別に追跡することで, 陸域に最終的に 漂着する可燃物の空間分布を評価することになるが，シミュレーシ ヨン結果から, 建物から流出した多数の可燃物の位置が, 津波数值 解析による津波氾濫流の計算結果を与条件として, 個別に予測され ていることが分かる。このシミュレーション結果では, 陸域に漂着 している可燃物, 陸域を漂流している可燃物, 海域に流れ出ている 可燃物が評価されている。

図 8 に, 被害モード別の建物棟数の評価結果を示す。ここでは, 津波氾濫流のシナリオごとに, 平均（積み上げ棒）と標準偏差（エ ラーバー）を算出した。なお，ここでの建物棟数は，津波によって 流出する可燃物の総量を表していると考えることもできる。被害モ 一ド別の建物棟数は, 潮位の違いよりも, 海岸構造物の被害の違い によって，大きな影響を受けていることが分かる。特に，海岸構造 物の機能が保持される条件とそうでない条件では, 潮位の違いによ らず，評価結果が大きく異なる結果が得られた。海岸構造物の機能 が保持される条件では, 高さ $4 \mathrm{~m}$ の防潮堤が, 浸水範囲や浸水深の 低減に, 特に大きな効果を発揮していると考えられる。海岸構造物

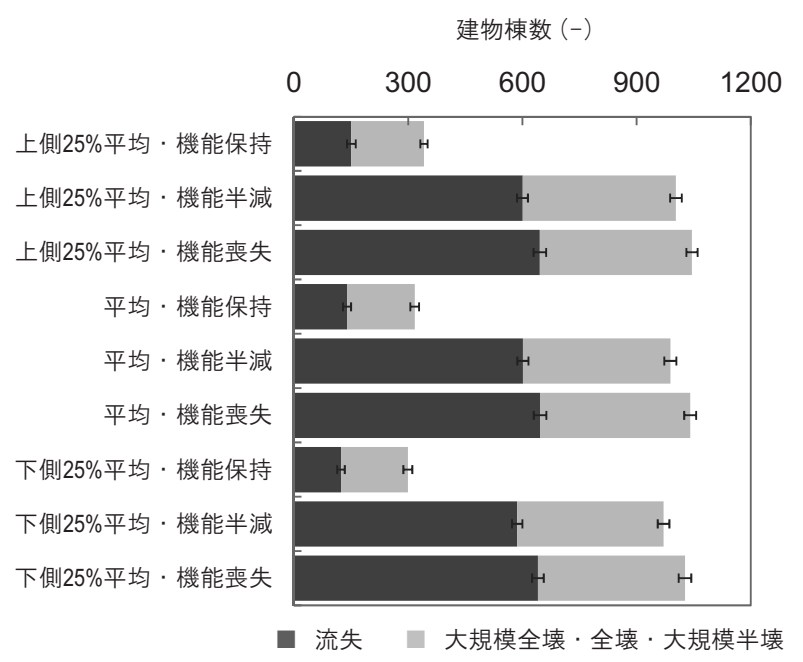

図 8 被害モード別の建物棟数の評価結果

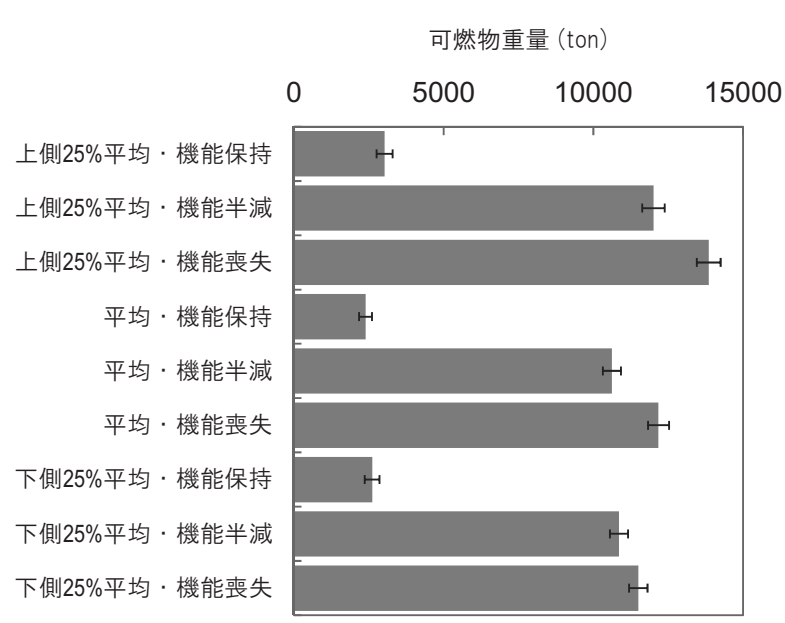

図 9 陸域に最終的に漂着した可燃物の総重量の評価結果 


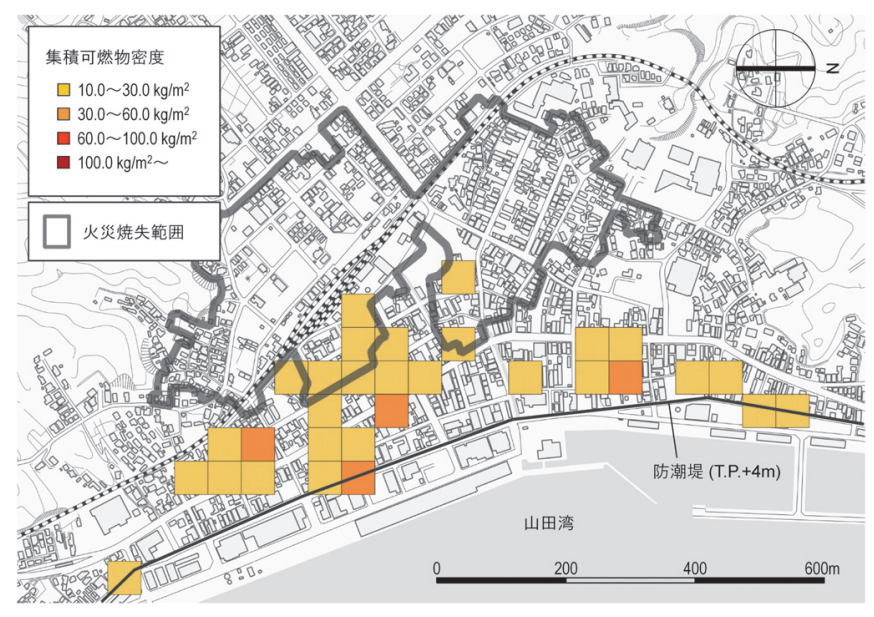

(a) 上側 $25 \%$ 平均 · 機能保持

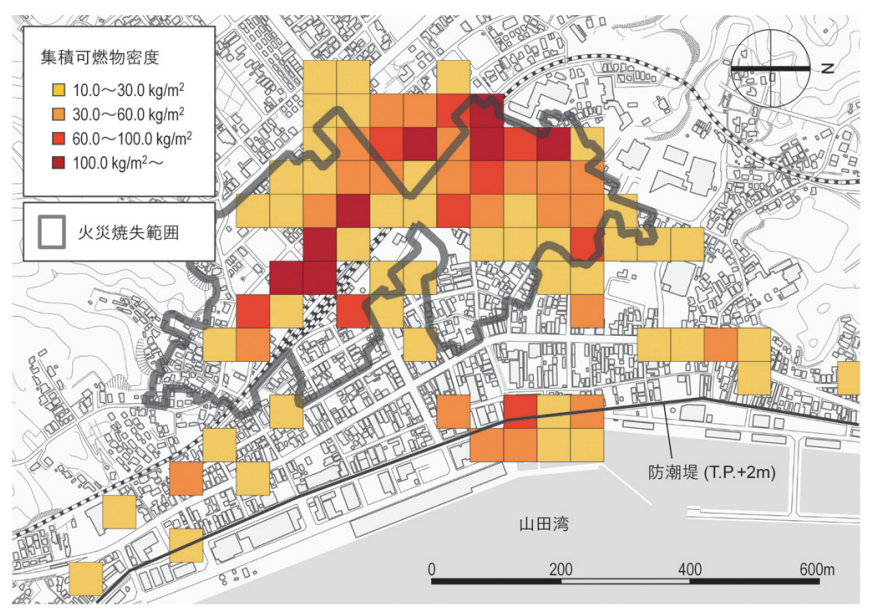

(b) 上側 $25 \%$ 平均 $\cdot$ 機能半減

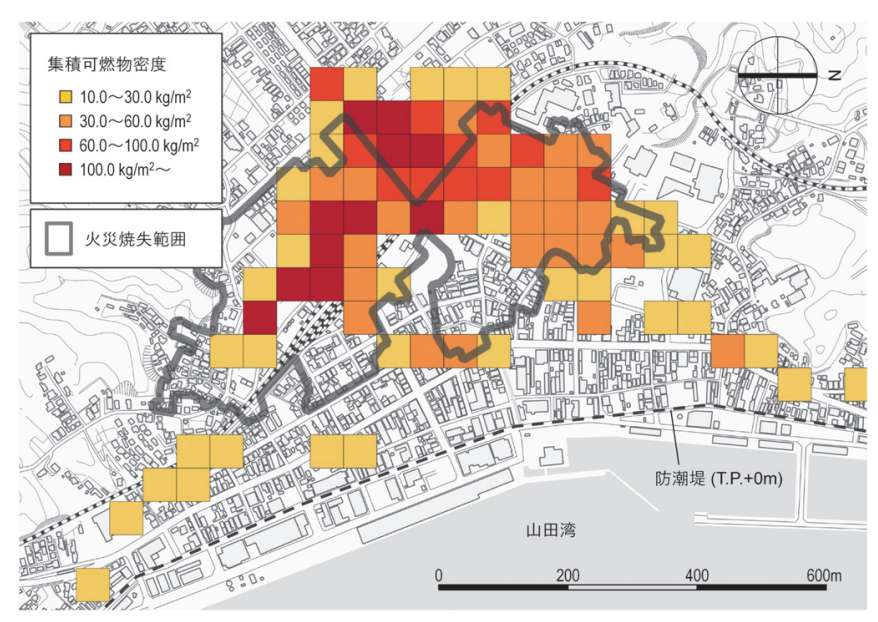

(c) 上側 $25 \%$ 平均 · 機能喪失

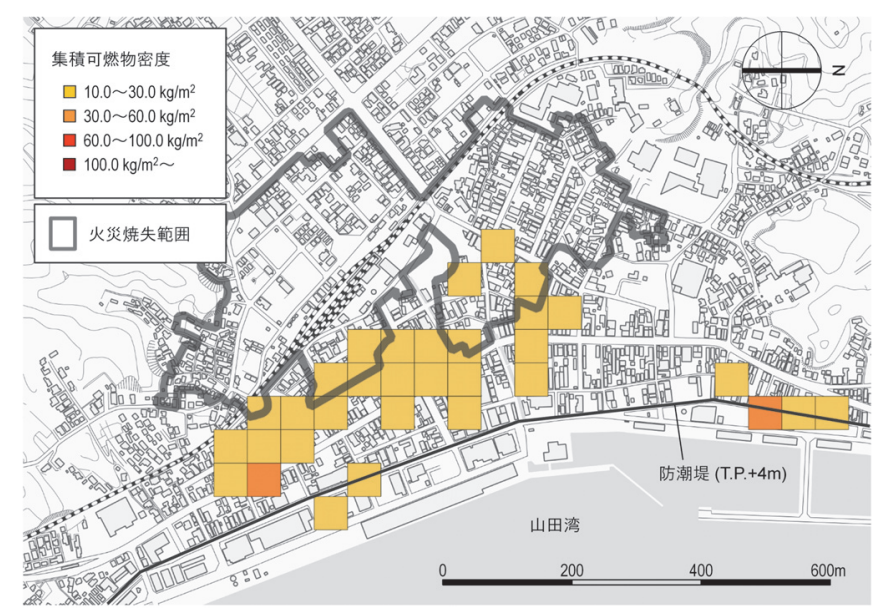

(d) 下側 $25 \%$ 平均 · 機能保持

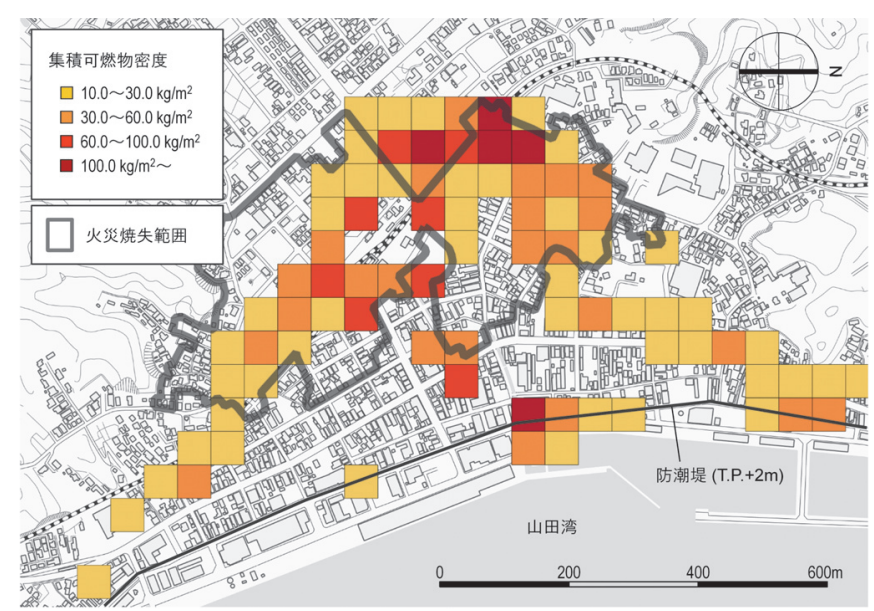

(e) 下側 $25 \%$ 平均 $\cdot$ 機能半減

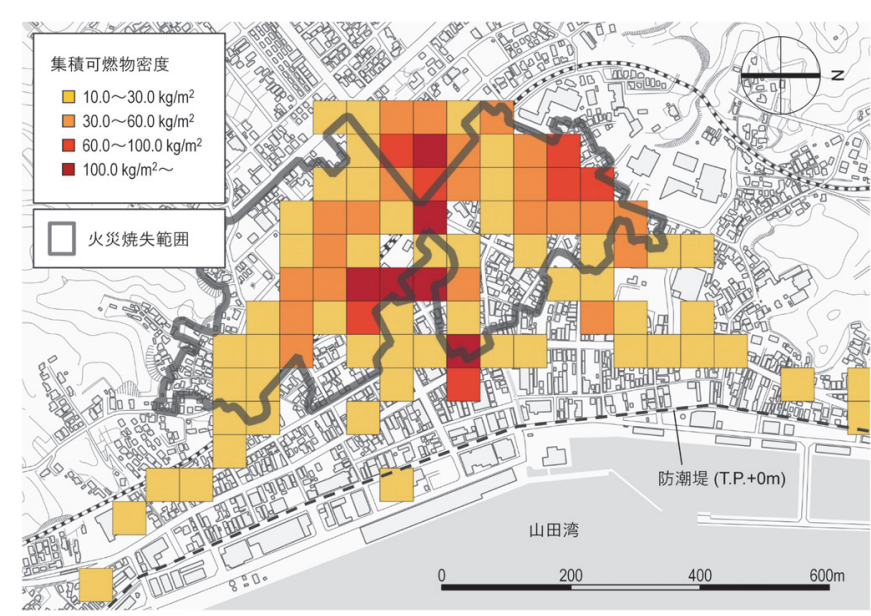

(f) 下側 $25 \%$ 平均 · 機能喪失

図 10 津波汇濫流が与えられた時の集積可燃物密度の平均 $\mu_{j k}$ の評価結果

の機能が保持される条件では, 流失と大規模全壊・全壊・大規模半 壞の間で，建物棟数に大きな差はないが，そうでない条件では，流 失が大規模全壊・全壊・大規模半壊の 2 倍程度となっている。これ は, そうでない条件では, 被害を受ける建物の中で, 浸水深の大き な建物が，多くを占めていることを表しており，津波氾濫流の強さ が大きいことが分かる。
図 9 に，陸域に最終的に漂着した可燃物の総重量の評価結果を示 す。ここでも，津波汇濫流のシナリオごとに，平均（棒）と標準偏 差（エラーバー）を算出した。なお，ここでの総重量は，建物から 流出した可燃物の総重量から, 陸域に漂着せずに, 海域に流れ出た 可燃物の総重量を引いたものと考えることもできる。陸域に漂着し た可燃物の総重量は, 潮位の違いによって, 若干の変化が生じてい 
るものの, 海岸構造物の被害の違いによって, 大きな影響を受けて おり, 被害モード別の建物棟数の評価結果と, 同様の傾向が表れて いる。特に, 海岸構造物の機能が保持される条件とそうでない条件 では, 評価結果に 4 6 倍程度の差が生じている。これは, 両者の間 で，建物から流出する可燃物の数が大きく異なることに関係してい る。

図 10 に, 津波汇濫流 $j$ が与えられた時の集積可燃物密度の平均 $\mu_{j k}$ の評価結果を示寸注 4$)$ ここでは, 評価結果が $10 \mathrm{~kg} / \mathrm{m}^{2}$ 未満の可 燃物密度が小さな箇所については, 可視化上除いて示してあるが, 集積可燃物密度の分布が不連続なように見えるのは，このことが原 因であることに注意する必要がある。集積可燃物は, 潮位の違いに よらず，海岸構造物の機能が保持される条件では，津波火災の焼失 範囲よりも，海側に集中しているが，そうでない条件では，焼失範 囲の内側や外側周辺に集中寸る結果が得られた。これは，両者の間 で，津波汇濫流の流況が，特に異なることに起因している。また， 陸域に漂着した可燃物の総重量との関係で, 海岸構造物の機能が保 持される条件では, 集積可燃物密度も, 全体的に小さな值となって いるが，そうでない条件では，集積可燃物密度が大きい箇所が，多 数表れている。海岸構造物の機能が保持されない条件では, 集積可 燃物密度が大きい箇所は, 潮位が低くなることで, 海側に移動して いることが分かる。これは, 潮位の低下によって, 津波氾濫流の流 況が変化することに起因している。評価結果を総じて見ると，ある 津波氾濫流では，集積可燃物密度が小さい箇所が，別の津波氾濫流 では, 大きい箇所となる結果が得られており, 集積可燃物密度の不 確定性が表れている。

図 11 に, ネットの集積可燃物密度の評価結果を示す。ここでは, 平均 $\mu_{n e t, k}$ に, 標準偏差 $\sigma_{n e t, k}$ の 3 倍を加えた結果を示した。これに よると, 集積可燃物密度が大きな箇所は, 津波火災の焼失範囲の内 側や外側周辺に集中しており, 海岸に近い箇所では，集積可燃物密 度が小さくなる結果が得られている。このことから, 本研究で提案 する手法は，実態を再現するための䩦密な条件で計算を行った訳で はないものの, 実際の火災焼失範囲を尤もらしく推定する結果とな った。これは, ネットの集積可燃物密度という指標が，ある地点の 津波火災による被害の受けやすさを表す危険度指標として, 有効で ある可能性を示唆している。

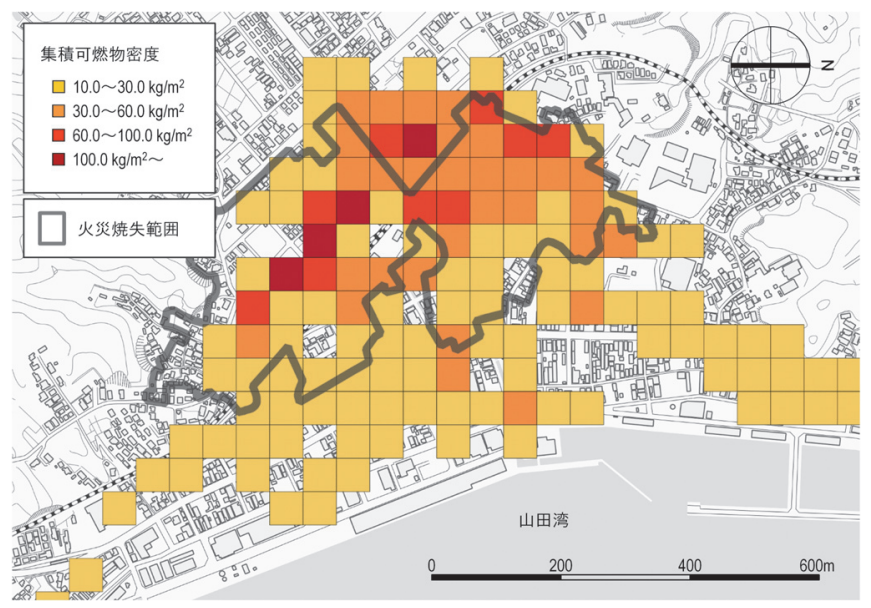

図 11 ネットの集積可燃物密度の評価結果 $\left(\mu_{n e t, k}+3 \sigma_{n e t, k}\right)$

\section{5. 南海トラフ地震の津波火災ハザードマップの推定}

本研究で提案する手法を, 南海トラフ地震津波に適用し, 津波火 災ハザードマップの推定を行った。ここでは, 内閣府 ${ }^{30)}$ の地震被害 想定の結果を参考に, 津波による大規模な被害が懸念される静岡県 下田市を対象とした。

\section{1 計算条件}

表 3 に, 計算条件を示す。モンテカルロ・シミュレーションは, 100 回の試行とし, 各試行につき, 地震から 5 時間分のシミュレー ションを行った。津波汇濫流のシナリオ数は, 9 通りであるため, 合計で 900 通りの集積シナリオとその生起確率を基に，ネットの集 積可燃物密度の平均 $\mu_{n e t, k}$ と標準偏差 $\sigma_{n e t, k}$ を評価することになる。 集積可燃物密度を評価するメッシュの幅は，50m と設定した。

津波断層モデルには, 内閣府 ${ }^{30)}$ の地震被害想定の成果を活用し, 駿河湾〜紀伊半島沖に，大寸心゙り域を設定したモデルを用いた。潮 位については, 下田市の 1 年分の潮汐表から, 平均と標準偏差を計 算し，3 種類の潮位を決定した。その結果，上側 $25 \%$ 平均潮位は, $0.642 \mathrm{~m}$, 平均潮位は， $0.156 \mathrm{~m}$, 下側 $25 \%$ 平均潮位は, $-0.330 \mathrm{~m}$ とな った。海岸構造物については, 下田湾口に設置されている防波堤を 考慮し，基礎である海底のマウンドには，被害が生じないものとし て，上方の堤体部分の高さを変化させることで，被害の影響を考慮 した。ここでは, 内閣府 ${ }^{30)}$ の海岸構造物データを基に, 堤体部分の 高さを $4 \mathrm{~m}$ と設定し, 機能半減の条件では, 高さを $2 \mathrm{~m}$ に, 機能喪 失の条件では, 高さを $0 \mathrm{~m}$ に変化させた。

建物の位置 - 形状 ・階数は, 最近の市街地状況が分かる住宅地図 から把握し，6,522 棟の建物をデータ化した。建物の構造について は，基盤地図情報から，普通建物・堅牢建物の種別を特定し，前者 を木造建物として扱った。また，建物の用途は，住宅地図と電話帳 データから，特定した。

その他の計算条件については, 東北地方太平洋沖地震津波を対象 とした評価と，同様に設定した。

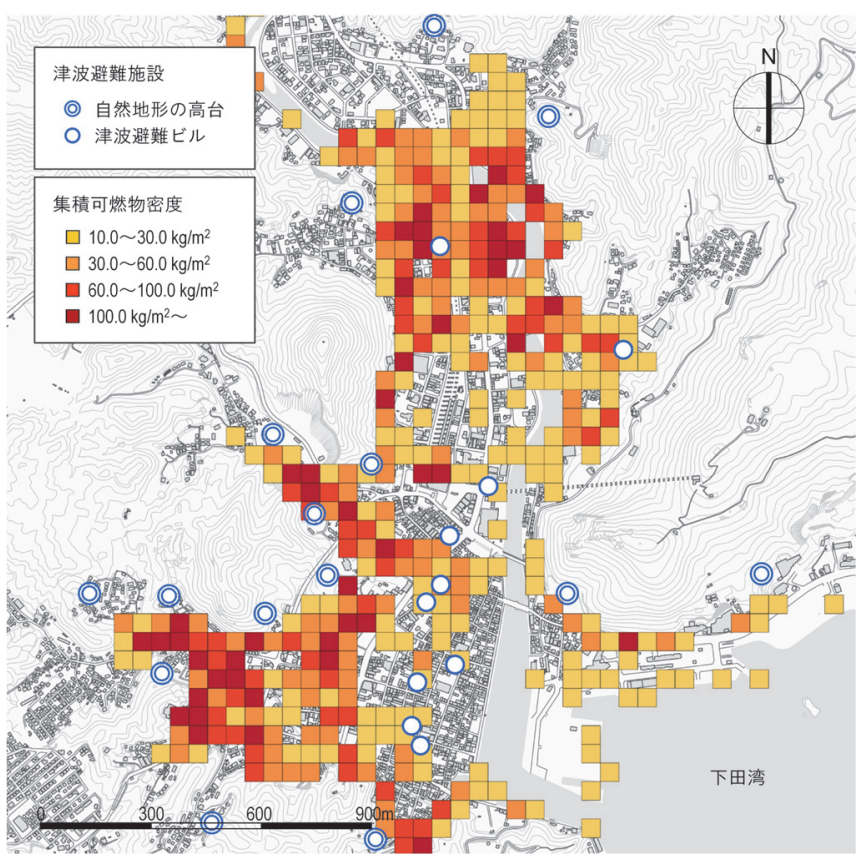

図 12 津波火災ハザードマップの推定結果 $\left(\mu_{n e t, k}+3 \sigma_{n e t, k}\right)$ 


\section{2 計算結果と考察}

図 12 に, 津波火災ハザードマップの推定結果を示す。ここでは, ネットの集積可燃物密度の平均 $\mu_{n e t, k}$ に, 標準偏差 $\sigma_{n e t, k}$ の 3 倍を加 えた結果を採用した。また, 津波からの避難施設として, 自然地形 の高台と津波避難ビルの位置を, プロットしてある。推定結果によ ると, 下田湾に近い津波避難ビルの周辺では, 集積可燃物密度が小 さい結果となっており, 津波火災によって被害を受ける危険性が比 較的小さいことが分かる。一方, 下田湾から市街地を進んだ所にあ る津波避難ビルの周辺では, 集積可燃物密度が大きな箇所が連続的 に広がっており，津波火災によって被害を受ける危険性が高いこと が分かる。こうした地域では, 集積可燃物密度が小さな箇所に, 津 波避難ビルの配置を変更寸るといった対策が考えられる。または, 鉄筋コンクリート造のように, 津波火災を受けても倒壊しにくい構 造であることや，防火区画や外気開放スペースなど，津波火災から 避難者を保護寸るために有効なスペースが，建物に觉長的に備わっ ていることが確認されれば, 配置を変更しなくても良いといった考 え方もある。ただし, 集積可然物密度が大きな箇所は, 自然地形の 高台の周辺にも, 多く存在する結果となっている。東北地方太平洋 沖地震では, 津波火災が林野火災を誘発した事例 ${ }^{5}$ が報告されてい ることから, 周辺の集積可燃物密度が大きい高台では, 林野火災に よって被害を受ける可能性を想定し，二次避難のための経路を整備 しておく必要性が考えられる。

\section{6. まとめ}

津波火災危険度の確率論的評価手法を提案した。ここでは，ある 地点の津波火災による被害の受けやすさを表す危険度指標として, その地点に最終的に漂着する可燃物の単位面積あたりの総重量（集 積可燃物密度）に着目した。提案した手法では, 筆者らが開発した 可燃物の漂流・集積モデルを活用し，多数の集積シナリオとその生 起確率を考慮して,ネットの集積可燃物密度を評価する。ここでは, 集積可燃物密度を左右寸る不確定要因として，(1)津波来襲時の潮位， (2)防潮堤といった海岸構造物の被害, (3)津波による建物の被害, (4) 建物に収納・固定される可燃物の密度, の 4 種類を考慮した。評価 にあたっては, 各不確定要因の影響をモデル化し, イベントッリー とモンテカルロ・シミュレーションを併用することで, 有限個の集 積シナリオを抽出した後, ネットの集積可燃物密度を算定する。

提案した手法の評価特性を確認するため, 東北地方太平洋沖地震 津波を対象とした津波火災危険度の評価を行った。岩手県山田町中 心部に着目した評価結果は, 実際の津波火災の焼失範囲を尤もらし く推定する結果となり, ネットの集積可燃物密度が, ある地点の津 波火災による被害の受けや寸さを表す危険度指標として, 有効であ る可能性が確認された。また, 提案した手法を南海卜ラフ地震津波 に適用し, 静岡県下田市を対象とした津波火災八ザードマップの推 定を行った。この推定結果に, 津波避難施設の現沉を重敉合わせ, 考察を加えた所, 提案した手法によって推定される津波火災八ザー ドマップは, 津波避難施設の配置や火災安全計画に有用であること が示された。

ただし, 本研究で提案した手法には, いくつかの課題が残されて いる。津波断層モデルの不確定性や, 海岸構造物の被害の位置の不 確定性については, 決定論的な扱いや簡略化がなされているが, 評
表 3 計算条件（南海トラフ地震・下田市）

\begin{tabular}{|c|c|c|}
\hline \multicolumn{2}{|c|}{ 項目 } & 設定 \\
\hline \multicolumn{2}{|c|}{ 津波氾濫流のシナリオ数 } & 9 \\
\hline \multicolumn{2}{|c|}{ モンテカルロ・シミュレーションの試行回数 } & 100 \\
\hline \multicolumn{2}{|l|}{ 計算時間 } & $5 \mathrm{hrs}$ \\
\hline \multirow{2}{*}{ 時間刻み } & 津波氾濫流の流況 & $0.1 \mathrm{~s}$ \\
\hline & 可燃物の位置変化 & $0.6 \mathrm{~s}$ \\
\hline \multirow{2}{*}{ メッシュの幅 } & 津波汇濫流の流況 & $10 \mathrm{~m}$ \\
\hline & 集積可燃物密度 & $50 \mathrm{~m}$ \\
\hline \multicolumn{2}{|l|}{ 津波断層モデル } & 内閣府モデル \\
\hline \multirow{3}{*}{ 潮位 } & 上側 $25 \%$ 平均潮位 & $0.642 \mathrm{~m}$ \\
\hline & 平均潮位 & $0.156 \mathrm{~m}$ \\
\hline & 下側 $25 \%$ 平均潮位 & $-0.330 \mathrm{~m}$ \\
\hline \multirow{3}{*}{$\begin{array}{l}\text { 海岸構造物の高さ } \\
\text { (防波堤) }\end{array}$} & 機能保持 & $4 \mathrm{~m}$ \\
\hline & 機能半減 & $2 m$ \\
\hline & 機能喪失 & $0 \mathrm{~m}$ \\
\hline \multirow{3}{*}{ 建物 } & 位置·形状·階数 & 住宅地図 \\
\hline & 構造 & 基盤地図情報 \\
\hline & 用途 & 住宅地図·電話帳 \\
\hline
\end{tabular}

価結果に及ぼす影響は小さくないと予想されるため, 改良の余地が ある。また, 本研究では, 集積可燃物密度の不確定性に着目して評 価を行ったが，ある地点の津波火災による受害可能性は，本来，出 火や延焼の不確定性を含めて評価される必要がある。津波火災によ って生じる損失の大きさとその生起確率を基に，津波火災リスクを 評価する手法を検討することで, 出火や延焼の不確定性を含めた評 価を実現できる可能性がある。

\section{謝辞}

本研究は, 日本学術振興会科学研究費補助金 若手研究 (A)「津 波による流出家屋に起因した「津波火災」のシミュレーションモデ ルの構築」（No. 15H05540）の助成を受けたものです。

注

注 1）津波は, 水深数 $\mathrm{km}$ の海底において, 数十〜数百 $\mathrm{km}$ の空間的広がりを もった地盤変動によって発生するため, 水深（鉛直）方向よりも水平方向 のスケールが，十分に大きい波であると言える。このため，津波現象の多 くの部分は，長波近似による流体力学の理論方程式で記述され，粘性を無 視した非圧縮性流体の 2 次元非回転問題として扱われる ${ }^{31}$ 。津波数值解析 では, こうした仮定の下, 次のような質量と運動量の保存式を, メッシュ を用いた有限差分法で解く。

$\frac{\partial \eta}{\partial t}+\frac{\partial M}{\partial x}+\frac{\partial N}{\partial y}=0$

$\frac{\partial M}{\partial t}+\frac{\partial}{\partial x}\left(\frac{M^{2}}{D}\right)+\frac{\partial}{\partial y}\left(\frac{M N}{D}\right)+g D \frac{\partial \eta}{\partial x}+\frac{g n^{2} M}{D^{7 / 3}} \sqrt{M^{2}+N^{2}}=0$

$\frac{\partial N}{\partial t}+\frac{\partial}{\partial x}\left(\frac{M N}{D}\right)+\frac{\partial}{\partial y}\left(\frac{N^{2}}{D}\right)+g D \frac{\partial \eta}{\partial y}+\frac{g n^{2} N}{D^{7 / 3}} \sqrt{M^{2}+N^{2}}=0$

ここに, $\eta$ は水位， $D$ は全水深， $g$ は重力加速度， $n$ は Manning の粗度 係数, $M$ と $N$ は $x$ 方向と $y$ 方向の流量フラックスである。ただし, 建物 が津波氾濫流に及ぼす影響は，その形状を地形モデルの中で陽に考慮する のではなく, 建物の密集度に応じた粗度係数 ${ }^{32)}$ を与えることで, 底面か らの摩擦力の一種と夕なし, 流れに与える抵抗を巨視的に考慮する。本研 究では, 簡単のため, 建物の流失被害に伴う抵抗の変化を無視し, 粗度係 数は，初期值のまま変化させない。

注 2）国土交通省による東北地方太平洋沖地震津波の建物被害調查 7) では, 被害モードの判定根拠を，「流失」が「基礎だけを残し，建物が完全に流 
されている」，「大規模全壊」が「主要構造が損壊しており，補修により 元通りに再利用寸ることが困難」，「全壊」が「1 階天井以上浸水してお り, 大規模修繕等による再利用も可能」，「大規模半壊」が「床から概ね $1 \mathrm{~m}$ 以上 (天井未満) 浸水」, 「半壊」が「床から概水 $1 \mathrm{~m}$ 未満の床上浸水」, 「一部損壊」が「床下の泥等を取り除けば再利用可能」としている。

注 3）津波火災によって, ある地点が被害を受ける条件は, その地点の周辺 に可燃物が集積し, 何らかの要因で出火が生じて, その地点に延焼する, といった過程で表すことができる。このため, ある地点の受害可能性は, 可然物の集積の不確定性だけでなく, 出火や延焼の不確定性にも, 影響を 受ける。しかし, 津波火災ハザードマップの危険度指標としての直観的な 分かりやすさや, 津波避難施設の火災外力の設定に活用することを考え, 本研究では, 集積可燃物密度の不確定性に着目した評価を行うこととし, 出火や延焼の不確定性を含めた評価は, 今後の課題とする。

注 4) 本研究では, 津波氾濫流 $j$ が与えられた時の集積可燃物密度 $w_{j k}$ が正 規分布に従うことを仮定している。ここでは, 各メッシュで得られる集積 可然物密度 $w_{j k}$ の平均と中央值の関係, および, 平均に $3 \sigma$ を加えた值と 99 パーセンタイルの関係を, 散布図を用いて確認した。その結果, いずれ も, 両者の值が概衩一致していたことから, 集積可燃物密度 $w_{j k}$ の正規分 布の仮定に, 大きな問題はないと考えられる。

\section{参考文献}

1) 消防庁消防研究センター : 平成 23 年（2011 年）東北地方太平洋沖地震の 被害及び消防活動に関寸る調査報告書（第 1 報），消防研究技術資料第 82 号, 2011

2) Hokugo A, Nishino T, and Inada T: Tsunami Fires after the Great East Japan Earthquake, Journal of Disaster Research, Vol.8, No.4, pp.584-593, 2013

3) 西野智研・北後明彦: 映像記録の観察を中心とした津波避難ビル周辺で発 生する火苂の事例研究，日本火災学会論文集，Vol.63，No.1，pp.1-8，2013

4) 野竹宏彰・森田武・近藤史朗・広田正之・水落秀木：東日本大震災の津波 火㷋における避難拠点建物の延焼拡大要因の分析と防火対策に関寸る考察, 清水建設研究報告, No.89, pp.57-66, 2012

5) 小林悟志: 2011 年の震災津波による二次災害で発生した岩手県大槌町の山 林火災の現状, 自然苂害科学, Vol.31, No.2, pp.145-153, 2012

6) 西野智研・今津雄吾・北後明彦・野竹宏彰 : 津波火災シミュレーションに 向けた建物から流出する可燃物の時空間分布予測モデル, 日本建築学会環 境系論文集，Vol.80，No.716，pp.857-866，2015.10

7) 国土交通省都市局: 東日本大震災からの津波被災市街地復興手法検討調査, http://www.mlit.go.jp/toshi/toshi-hukkou-arkaibu.html（2014/12/1 閲覧）

8) 土木学会原子力土木委員会津波評価部会 : 確率論的津波ハザード解析の方 法, 2011

9) 岩㴊洋子・杉野英治・蛯澤勝三 : 確率論的手法に基づく基準津波策定手引 き, 原子力安全基盤機構, 2014

10) 福谷陽 - Suppasri Anawat - 安倍祥 - 今村文彦 : 確率論的津波遡上評価と 津波リスクの定量化, 土木学会論文集 B2（海岸工学），Vol.70, No.2, pp.1381-1385, 2014

11) 国土開発技術研究センター編 : 建築物の総合防火設計法（第 4 巻 耐火 設計法），日本建築センター, 1989

12）油野健志 - 山仲秀利 - 大宮喜文 - 高橋清 - 田中哮義 - 若松孝旺 : 実態調 査に基づく可燃物量とその表面積の分析, 日本建築学会計画系論文集, No.483, pp.1-8, 1996.5

13) 久宝保・竹沢三雄: 海岸構造物の設計基準水面について, 第 11 回海岸工 学講演会講演集, pp.228-233, 1964

14) 稲富隆昌・善功企・外山進一 ・上部達生・井合進 - 菅野高弘・寺内潔 横田弘・藤本健幸 · 田中祐人 ·山崎浩之 - 小泉哲也 - 長尾毅 - 野津厚 - 宮 田正史・ 一井康二・森田年一 - 南兼一郎 - 及川研 - 松永康男 - 石井正樹 . 杉山盛行・高崎伸彦・小林延行・岡下勝彦 : 1995 年兵庫県南部地震による 港湾施設等被害報告, 港湾技研資料, No.857, 1997

15) 熊谷兼太郎 - 渡邊祐二・長尾憲彦 - 鮎貝基和 : 2011 年東北地方太平洋沖 地震津波による海岸保全施設の被害調査, 国土技術政策総合研究所資料, No.658, 2011

16）熊谷兼太郎・永廣迪・淺井正・宮田正史・松田茂・熟谷忠彦・鎌木雅之： 2011 年東北地方太平洋沖地震津波による海岸保全施設の被害調査 (その 2), 国土技術政策総合研究所資料, No.781，2014

17) 加藤広之 ・ 中村隆 - 鈴木彰 : 東北地方太平沖地震津波による漁港海岸保 全施設の被災メカニズムの検討, 一般財団法人漁港漁場漁村総合研究所, 調查研究論文集, No.22, pp.7-15, 2012
18) 越村俊一・行谷佑一・柳澤英明: 津波被害関数の構築, 土木学会論文集 B, Vol.65, No.4, pp.320-331, 2009

19) 越村俊一・萱場真太郎：1993 年北海道南西沖地震津波の家屋被害の再考 一津波被害関数の構築に向けて一, 日本地震工学会論文集, Vol.10, No.3, pp.87-101, 2010

20) Suppasri A, Mas E, Charvet I, Gunasekera R, Imai K, Fukutani Y, Abe Y, and Imamura F: Building Damage Characteristics Based on Surveyed Data and Fragility Curves of the 2011 Great East Japan Tsunami, Natural Hazards, Vol.66, pp.319-341, 2013

21）日本建築学会：建築物の火災荷重および設計火災性状指針（案），2013

22）松山賢・林吉彦・清水恵一・野崎洋之・小林裕・中濱慎司：工場出火時 の延焼拡大と近隣住居一の類焼予測に関寸る研究その 1 工場可燃物実態 調査結果について, 日本建築学会関東支部研究報告集 I, Vol.75, pp.317-320, 2005

23）国土交通省総合技術開発プロジェクト：まちづくりにおける防災評価・ 対策技術の開発 報告書, 国土交通省, 2003

24）今村文彦・越村俊一・馬㴊幸雄 - 大家隆行 ・ 岡田清宏 : 東北地方太平洋 沖地震を対象にした津波シミュレーションの実施,

http://www.tsunami.civil.tohoku.ac.jp/hokusai3/J/events/tohoku_2011/model/dcrc _ver1.2.pdf（2014/12/1 閲覧）

25) 国土交通省都市局：『復興支援調査アーカイブ』データ，

http://fukkou.csis.u-tokyo.ac.jp/（2014/12/1 閲覧）

26) 後藤智明・首藤伸夫・佐々木順次 : 津波による木材の流動, 第 29 回海岸 工学講演会論文集, pp.491-495, 1982

27) 秋山壽一郎・重枝末玲 - 小林俊彦・大田和正 : 定常自由表面流中の正角 柱に働く流体力, 水工学論文集, Vol.46, pp.827-832, 2002

28) Elder, J. W.: The Dispersion of Marked Fluid in Turbulent Shear Flow, Journal of Fluid Mechanics, Vol. 5, p.544-560, 1959

29) 中川一・高橋保・池口正晃 : 流木群の流動に関する研究, 京都大学防災 研究所年報, No.35, B-2, pp.249-266, 1992

30) 内閣府 : 南海トラフ巨大地震の震度分布、津波高等及び被害想定につい $\tau, 2012$

31) IOC (Intergovernmental Oceanographic Commission): IUGG/IOC TIME PROJECT, Numerical Method of Tsunami Simulation with the Leap-frog Scheme, UNESCO, pp.1-24, 1997

32) 小谷美佐・今村文彦・首藤伸夫 : GIS を利用した津波遡上計算と被害推定 法, 海岸工学論文集, Vol.45, pp.356-360, 1998 


\title{
A METHOD FOR ESTIMATING TSUNAMI-INDUCED FIRE HAZARD MAP FOCUSING ON UNCERTAINTY OF ACCUMULATING COMBUSTIBLE DENSITY
}

\section{Tomoaki NISHINO* and Yugo IMAZU**}

\author{
* Senior Research Engineer, Building Research Institute, Dr. Eng. \\ ** Senior Research Engineer, Institute of Technology, Shimizu Corp., M. Eng.
}

\begin{abstract}
We proposed a probabilistic method for evaluating a hazard map for tsunami-induced fire. Accumulating combustible density is used as the indicator visualized on the map, which represents the fire vulnerability of an arbitrary point. The accumulating combustible density is evaluated on the basis of multiple accumulation scenarios and their occurrence probabilities using the existing model for the drift and accumulation of tsunami-driven combustible objects. Here, the following factors are defined as the uncertain factors which governs the accumulation scenarios: 1) sea level in the event of tsunami arrival, 2) damage of coastal structures such as a seawall, 3) damage of buildings, and 4) density of movable and fixed combustible objects loaded on buildings. A finite number of accumulation scenarios are sampled to evaluate the average and the standard deviation of accumulating combustible density using event tree and Monte Carlo simulation.

We applied the proposed method to Yamada town in the 2011 Great East Japan Earthquake Tsunami to verify the evaluation characteristics. Field survey after the tsunami has reported that two fires broke out in tsunami inundation area of Yamada town and developed into spreading fires resulting in 16 hectares of burned area. As a result, the proposed method could estimate the actual fire damage zone plausibly, because high accumulating combustible density areas are concentrated within or around the fire damage zone. This result indicates that the accumulating combustible density is available as the indicator of tsunami-induced fire hazard map which represents the fire vulnerability of an arbitrary point.

A tsunami-induced fire hazard map of future Nankai Trough Earthquake was estimated using the proposed method. Here, Shimoda city was adopted as the target area of hazard map estimation, and safety of tsunami refuge facilities against the fire was considered by overlaying the high grounds and the tall buildings on the map. The result shows that the hazard map estimated by the proposed method is useful for planning of location and fire safety of tsunami refuge facilities.
\end{abstract}

